\title{
Extraction of starch from Hass avocado seeds for the preparation of biofilms
}

\author{
Rosalía JIMÉNEZ1 , Gloria SANDOVAL-FLORES², Sofía ALVARADO-REYNA ${ }^{2 *}$ (D), \\ Sanjuana Elizabeth ALEMÁN-CASTILLO ${ }^{3}$, Rubén SANTIAGO-ADAME², Gonzalo VELÁZQUEZ ${ }^{4}$
}

\begin{abstract}
Biofilms arise as an alternative to replace synthetic polymers, which have generated environmental pollution. The aim of this work was to extract starch from Hass avocado seeds (Persea americana Mill) to produce biofilms. Starch was extracted using the wet method and characterized by infrared spectroscopy. Moisture, ash content, gelatinization temperature, and color were determined. Two types of biofilms were produced: T1 (starch) and T2 (starch and glycerol). The colour was measured, and the films were characterized by mechanical tests. A yield of $11.38 \%$ was obtained for the isolated starch. Glycerol addition significantly influenced the tensile strength being $\mathrm{T} 1$ higher than T2. In elongation percentage, $\mathrm{T} 1$ was lower than T2. The results indicate that it is possible to use Hass avocado seed waste for starch extraction and produce biofilms to give it added value. This biofilm can be used in low moisture food coatings.
\end{abstract}

Keywords: biofilm; Hass avocado seed; starch; glycerol; mechanical properties.

Practical Application: It is possible to use Hass avocado seed waste for starch extraction and produce biofilms to give it added value. This biofilm can be used in low moisture food coatings.

\section{Introduction}

Synthetic polymers or other derived from non-renewable resources, usually of lower cost and limited or minimal biodegradability, have exceptional mechanical and thermal properties (Rodríguez-Sepúlveda \& Orrego-Alzate, 2016). Biopolymers can be a solution to environmental impacts caused by plastics since they can easily degrade in the environment and imitate the properties of conventional polymers (Yadav et al., 2018).

Starch is a natural, renewable, and biodegradable polymer; it is the second most abundant biomass material in nature (Le Corre et al., 2010). It is found in different parts of plants, including fruits, tubers, roots, and seeds. In addition to its low density and low production cost, starch has become the ideal material for use in several applications including packaging and agriculture (Pérez, 2014). Starch can be obtained from unconventional sources such as avocado seed (Persea americana Mill) which belongs to the Lauraceae family (Chil-Núñez et al., 2019). Avocado is a species native to Mexico and Central America; the most commercialized varieties are Hass, Fuerte, and Nabal (Pérez et al., 2015). The Hass variety is medium size (150-400 g) with a rough green skin that turns black when ripe (Domínguez et al., 2014). Mexico is the main supplier to the international market, contributing $45.95 \%$ of the value of exports, with a production of $1,644,000$ tons, followed by the Dominican Republic with a production of 387,546 tons per year. In Mexico, the Agrifood and Fishery Information Service
(SIAP) of the Ministry of Agriculture and Rural Development (SAGARPA) reported, in the monthly bulletin January 2020, a total production of 206,466 tons, with Michoacan contributing on $94.6 \%$ (195,366 tons) to the national total, followed by Jalisco with $4.7 \%$ (9,759 tons). These two states concentrate 99.4\% (205,125 tons) of the country's production (Servicio de Información Agroalimentaria y Pesquera, 2020).

The obtained by-products from the avocado are the peel and the seed, which are often discarded. This waste is approximately $15 \%$ of total weight and is commonly discarded or used as a compost (Lara-Valencia et al., 2018). Both, the avocado peel, and seed have-high value compounds that can be extracted and used in various industries, which would lead to full exploitation of the fruit (Wang et al., 2010). Seed chemical composition on Hass and Fuerte varieties are 2.4 and $2.5 \%$ protein, 3.5 and $2.2 \%$ sugar, 2.5 and $3.2 \%$ neutral lipids, 12 and $13 \%$ glycolipids, 7.4 and $10.9 \%$ phospholipids, 0.8 and $1.0 \%$ fat, as well as 27.5 and $29.6 \%$ starch, respectively (Chil-Núñez et al., 2019). The seed is a source of non-conventional starch, and its characteristics are similar to those of corn starch. Seed starch functional and rheological properties suggest that it could have several potential applications as an ingredient in food systems and other industrial processes (Chel-Guerrero et al., 2016; Lara-Valencia et al., 2018). The aim of this study was to extract starch from the seed of Persea americana Mill for biofilms production adding commercial value to such waste and reduce its environmental impact. 


\section{Materials and methods}

\subsection{Starch extraction}

Starch was isolated by adapting Villalobos methodology (Villalobos et al., 2014), with modifications. The seed was washed with tap water and finally with distilled water before cutting it into $3 \mathrm{~cm}$ pieces. A sample of $300 \mathrm{~g}$ of cut seed was immersed in distilled water for $24 \mathrm{~h}$, then ground in a food processor (Oster FPSTFP1355 - 500W) to reduce the particle size by passing it through an 80-micron sieve. A $1000 \mathrm{~mL}$ of distilled water was added, left to stand for $1 \mathrm{~h}$, and finally filtered through a cloth sieve (cotton fabric). The suspension obtained was left to stand for $12 \mathrm{~h}$ to complete the starch sedimentation. The suspension was decanted and dried in an oven (Model 23 Binder, Germany) for $6 \mathrm{~h}$ at $42{ }^{\circ} \mathrm{C}$, ground and stored in a hermetically sealed container until use. The starch extraction process yield was calculated using Equation 1.

$$
\text { Yield }(\%)=\left(\frac{F W}{I W}\right) \times 100
$$

where: FW: Final weight (g); IW: Initial weight (g).

\subsection{Starch characterization}

Infrared spectroscopy was used (Nicolet iS10 FT-IR Spectrometer from Thermo Scientific FT- IR, Madison, Wisconsin, USA). A starch sample (1 g) was placed in the glass area at $25{ }^{\circ} \mathrm{C}$. Thirty-two sweeps were performed with a collection duration of $47.7 \mathrm{~s}$, resolution of $4 \mathrm{~cm}^{-1}$ and a spectral range of $400-4000 \mathrm{~cm}^{-1}$. The spectrum analysis was performed to identify the functional groups.

\subsection{Physico-chemical characteristics of starch (Persea americana Mill.)}

The moisture content was determined in accordance with NMX-F-083-1986 using Equation 2 (México, 1986). The ash was determined in accordance with NMX-F-066-S-1978 using Equation 3 (México, 1978).

$$
\operatorname{Moisture}(\%)=\left(\frac{W 1-W 2}{W 3}\right) \times 100
$$

where: $\mathrm{W} 1=$ weight of the container with the wet sample $(\mathrm{g})$; W2=weight of dry sample container $(\mathrm{g})$; W3=weight of the sample (g).

$$
\text { Ashcontent }(\%)=\left(\frac{P-p}{M}\right) \times 100
$$

where: $\mathrm{P}=$ weight of the crucible with the ash $(\mathrm{g}) ; \mathrm{p}=$ weight of empty crucible $(\mathrm{g}) ; \mathrm{M}=$ sample weight $(\mathrm{g})$.

\subsection{Starch gelatinization temperature}

Starch ( $2 \mathrm{~g})$ was dissolved in $70 \mathrm{~mL}$ of distilled water. A $250 \mathrm{~mL}$ of distilled water were heated to $85^{\circ} \mathrm{C}$ in a different container, to which $50 \mathrm{~mL}$ of the first precipitate were added by constant agitation with a glass rod until a paste was formed and the temperature remained stable in the range of 50 to $85^{\circ} \mathrm{C}$ for instrumental measure (Grace, 1977).

\subsection{Avocado seed starch colour evaluation}

The colorimetry study using the International Commission of I'Éclairage (CIE $L^{*} a^{\star} b^{*}$ ) system (MiniScan XE plus, Reston, Virginia, USA) was performed. The magnitude for color characterization were: Lightness $\left(\mathrm{L}^{\star}\right)$ from 0 to 100 , red-green ratio $\left(a^{\star}\right)$, and yellow-blue ratio $\left(b^{\star}\right)$. Saturation or purity (chroma) and hue (Hue) were calculated using Equations 4 and 5. The equipment was calibrated with reference tiles, first with the white tile taking a reading and then with the black tile repeating the same procedure. The samples were placed on a table-shaped surface at the reading port, taking readings at different sample points using as a reference point for comparison (GarcíaTejeda et al., 2011). The average value of all the determinations of the parameters $L^{*}, a^{*}$, and $b^{*}$ was reported.

$$
C^{*}=\sqrt{a^{2}+b^{2}}
$$

$h^{\circ}=s o^{-1}\left(b^{*} / a^{*}\right)$

\subsection{Biofilms production}

The biofilms were produced by the casting method following the procedure reported by Acosta (2011) with adaptations. Two types of biofilms were formulated: T1 (biofilm without plasticizer) and T2 (biofilm with plasticizer) maintaining the composition of $2 \mathrm{~g}$ of starch in $70 \mathrm{~mL}$ of distilled water. A $0.5 \mathrm{~mL}$ of glycerol was used as a plasticizer. $70 \mathrm{~mL}$ of distilled water were heated by adding $2 \mathrm{~g}$ of starch until its gelatinization, maintaining a constant agitation for $30 \mathrm{~min}$. In T2, $0.5 \mathrm{~mL}$ of glycerol was added as a plasticizer during the gelatinization. Finally, the starch suspension was transferred to $10 \times 10 \mathrm{~cm}$ plates and dried for $72 \mathrm{~h}$ in an oven at a constant temperature of $30^{\circ} \mathrm{C}$.

\subsection{Film thickness}

The biofilms thickness was measured with a micrometer (Mitutoyo absolute, Tokyo, Japan). The samples were taken at five random points. After measuring the films, the average and standard deviation were obtained (Alvarado et al., 2015).

\subsection{Tensile strength and break elongation}

The samples were cut in rectangles measuring $1 \times 9 \mathrm{~cm}$ using an acrylic mold and a cutter according to the specifications of ASTM D882-02 (American Society for Testing and Materials, 2001a) and conditioned for 5 days in a desiccator with a supersaturated solution of sodium bromide $(\mathrm{NaBr})$ to generate an environment of $57 \%$ relative humidity. The thickness of each film sample was determined at 5 randomly selected points. A texture analyzer (TA Plus, Lloyd Instruments, Largo, FL) equipped with mechanical grips with an initial separation of $50 \mathrm{~mm}$ was used, operating at a crosshead speed of $1 \mathrm{~mm} / \mathrm{s}$. For the test, 20 replicates were measured from two batches and the values of the samples that were fractured at the center of the film were taken. The average and standard deviation were obtained $(n=10)$. 


\subsection{Water vapor permeability}

According to the ASTM E96-00 method (American Society for Testing and Materials, 2001b) with some modifications, the water vapor permeability analysis was performed. A glass cell with an internal diameter of $3.4 \mathrm{~cm}$, a depth of $4 \mathrm{~cm}$, a film exposure area of $0.000908 \mathrm{~m}^{2}$ and a drilled lid was used. The films were cut in $4 \mathrm{~cm}$ diameter circles and fixed between 2 silicone gaskets in the cell lid containing distilled water to reach a relative humidity close to saturation. The cell was placed inside a double-walled acrylic container and silica gel was placed between the two walls. The inner wall was perforated to allow the silica gel to absorb moisture to create a dry environment around the cell and film. An analytical balance was used to record the weight of the permeability cell every minute. The temperature inside the cell was kept constant at $30^{\circ} \mathrm{C}$ and each test lasted $6 \mathrm{~h}$. Triplicate determinations were made. Weight loss was recorded as a function of time and the Equation 6 was used to calculate water vapor permeability in the region where the rate of weight loss was constant.

$$
P V A(g / m s P a)=Q * l / A^{*} \Delta P
$$

where: $\mathrm{Q}=$ is the weight loss per time unit $(\mathrm{t}) ; \mathrm{l}=$ is the thickness of the film (mm); $\mathrm{A}=$ is the transfer area $(\mathrm{m}) ; \Delta \mathrm{P}=$ is the water vapor pressure gradient $(4,245 \mathrm{~Pa})$ generated by distilled water and silica gel at $30^{\circ} \mathrm{C}$.

\subsection{Statistical data analysis}

A $t$-Student test was conducted to compare fracture stress, elongation, thickness, and water vapor permeability. Samples were performed to compare the T1 (biofilm without plasticizer) and T2 (biofilm with plasticizer) treatment, with a significance value $(p \leq 0.05)$. The data was analyzed in the statistical program SPSS version 22 for Windows (SPSS Inc., Chicago, IL, USA).

\section{Results and discussion}

\subsection{Starch yield}

The amount of starch extracted from Hass avocado seed was $34.13 \mathrm{~g}$ of dry starch $\left(45^{\circ} \mathrm{C}\right)$ obtained from $300 \mathrm{~g}$ of sample, representing a yield of $11.38 \%$. Lubis et al. (2016) reported a starch yield of $16 \%\left(60{ }^{\circ} \mathrm{C}\right)$ which differs by $4.62 \%$ with the present study. Ginting et al. (2015) reported a starch yield of $24.20 \%$ with a difference of $12.96 \%$ with the present study. Correa et al. (2019) reported a starch yield of $4.5 \%$ lower than the present study. The mentioned authors used Hass avocado seed as raw material employing sodium hydroxide and sodium metabisulfite for extraction.

\subsection{Starch characterization}

Figure 1 shows the infrared spectrum of starch obtained from an avocado seed. The vibrations at $3,296 \mathrm{~cm}^{-1}$ are associated to the stretching of the hydroxyl $(\mathrm{OH}-)$ functional group. The signals observed in the wavelength of $2,919 \mathrm{~cm}^{-1}$ correspond to the band of the vibrations of the carbon-hydrogen $(\mathrm{C}-\mathrm{H})$ bonds of the methyl groups. The wavelength at $1,418 \mathrm{~cm}^{-1}$ is identified as carbon-carbon (C-C) bond of the carboxyl groups, and finally, the signal at $1,242 \mathrm{~cm}^{-1}$ is attributed to the deformation of the methyl group $(\mathrm{C}-\mathrm{H})$. The main functional groups in avocado seed starch were observed mostly in the range from 3,294 to $3,296 \mathrm{~cm}^{-1}$ since this signal is attributed to the stretching of starch hydroxyl groups vibrations, which is within the mentioned range (Hernández et al., 2017).

\subsection{Physicochemical characteristics of Hass starch (Persea americana Mill.)}

A chemical analysis was conducted to determine the amount of moisture and ash. Table 1 show the values obtained from this analysis. Cornelia \& Christianti (2018) reported $11.33 \%$ moisture in Hass avocado seed starch, similar to this study. Ash

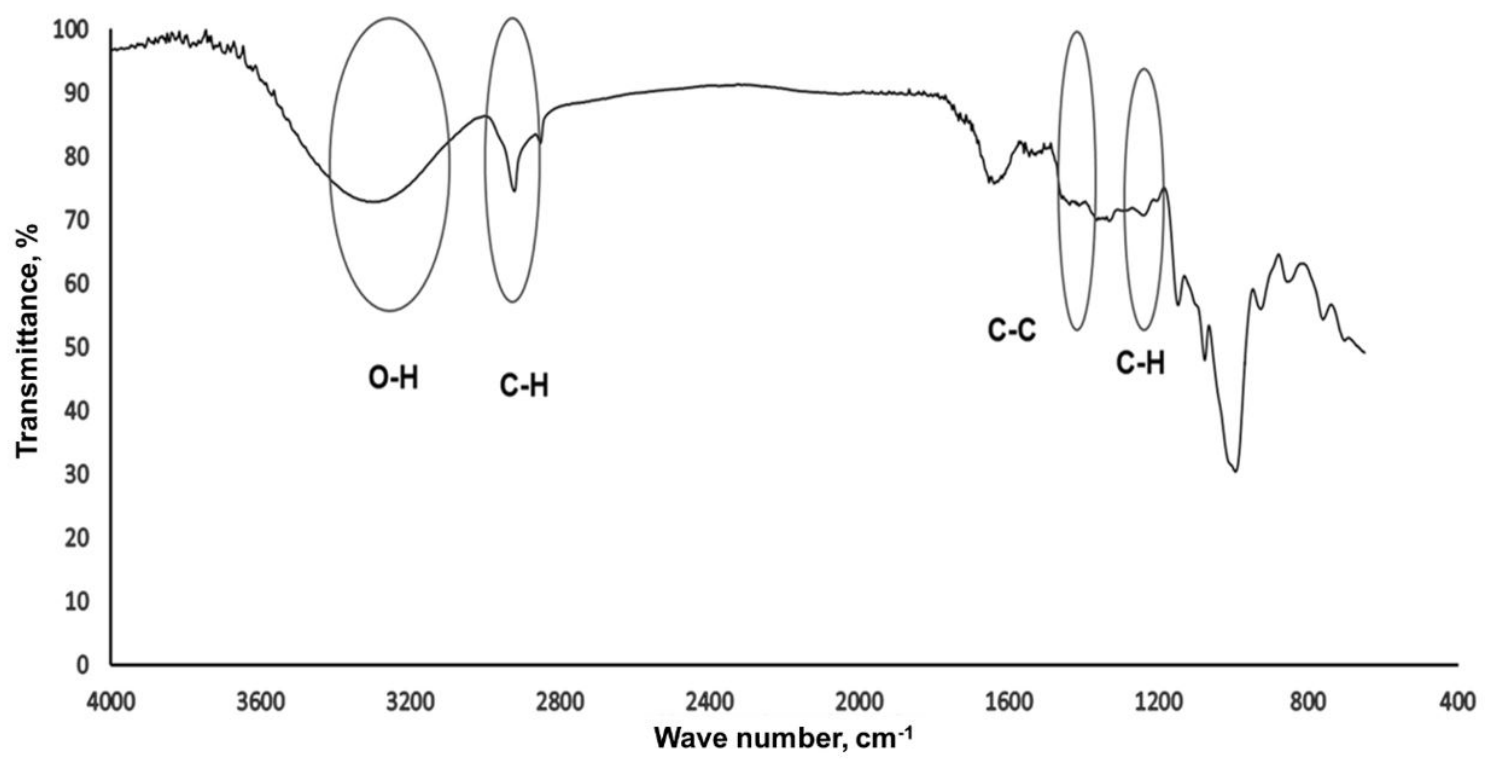

Figure 1. FTIR spectrum with characteristics absorption bands of Hass avocado seed starch. 
Table 1. Physicochemical characteristics of Hass avocado seed starch.

\begin{tabular}{cc}
\hline Analysis & Content \\
\hline Moisture & $12.00 \pm 0.50$ \\
Ashes & $0.16 \pm 0.0$ \\
\hline
\end{tabular}

Results are the average $(n=3) \pm$ standard deviation value.

Table 2. Biofilm color parameters.

\begin{tabular}{crcc}
\hline Parameter & \multicolumn{1}{c}{ T1 } & T2 & p- value \\
\hline $\mathrm{L}^{*}$ & $84.3 \pm 0.52$ & $73.022 \pm 0.48$ & 0.95 \\
$\mathrm{a}^{*}$ & $7.20 \pm 0.09$ & $12.47 \pm .133$ & 0.56 \\
$\mathrm{~b}^{*}$ & $18.62 \pm 0.46$ & $31.582 \pm 0.265$ & 0.15 \\
croma & $19.96 \pm 0.44$ & $31.47 \pm 0.76$ & 0.05 \\
Hue & $68.85 \pm 0.46$ & $68.452 \pm 0.11$ & 0.001 \\
\hline
\end{tabular}

T1: biofilm without plasticizer; T2: biofilm with plasticizer. ${ }^{\star} t$-student Test $(\mathrm{p} \leq 0.05)$.

Table 3. Comparison Starch color.

\begin{tabular}{lcrr}
\hline \multicolumn{1}{c}{ Starches } & $\mathrm{L}^{*}$ & $\mathrm{a}^{*}$ & $\mathrm{~b}^{*}$ \\
\hline Hass avocado seed $_{\text {Banana }^{1}}$ & 73.02 & 12.47 & 31.58 \\
Sweet potato $^{2}$ & 81.33 & 4.29 & 10.07 \\
\hline
\end{tabular}

${ }^{1}$ García-Tejeda et al. (2011); ${ }^{2}$ Abegunde et al. (2013).

Table 4. Results of stress at fracture and elongation.

\begin{tabular}{lccc}
\hline \multicolumn{1}{c}{ Test } & T1 & T2 & p- value \\
\hline Stress at fracture, $\mathrm{MPa}$ & $19.37 \pm 5.30$ & $10.78 \pm 1.07$ & 0.001 \\
Elongation, \% & $3.07 \pm .55$ & $13.09 \pm 4.04$ & 0.001 \\
\hline
\end{tabular}

${ }^{*} t$-student Test $(\mathrm{p} \leq 0.05)$.

Table 5. Water vapor permeability.

\begin{tabular}{ccc}
\hline Sample & Permeability & $p$-value \\
\hline T1 & $1.42 \mathrm{E}-05 \pm 2.33 \mathrm{E}-06 \mathrm{~g} /$ day $\mathrm{mPa}$ & \multirow{2}{*}{0.017} \\
$\mathrm{~T} 2$ & $3.98 \mathrm{E}-03 \pm 1.09 \mathrm{E}-03 \mathrm{~g} /$ day $\mathrm{mPa}$ & \\
\hline
\end{tabular}

${ }^{*} t$-student Test $(\mathrm{p} \leq 0.05)$.

results obtained by Ginting et al. (2015) reported 1.03\% in Hass avocado seed starch. Ginting et al. (2018) reported $0.23 \%$ ash in a different variety of avocado. The reported results are superior to those found in this study.

\subsection{Starch gelatinization temperature}

The initial gelatinization temperature was $55^{\circ} \mathrm{C}$ and the final gelatinization temperature was $80^{\circ} \mathrm{C}$. Martínez et al. (2016) reported the initial gelatinization temperature of $72.10^{\circ} \mathrm{C}$ and the final gelatinization temperature of $87.0^{\circ} \mathrm{C}$ of orito banana starch. Alves et al. (2017) reported that the gelatinization temperature of avocado seed starch started at 43.17 and ended at $94.65^{\circ} \mathrm{C}$. The authors used differential scanning calorimetry. The temperature ranges used for starch gelatinization in the present study were within the ranges of the authors mentioned above; however, the final temperature is wider compared to that reported by Chel-Guerrero et al. (2016) who recorded a temperature range for gelatinization of avocado seed starch from 56.15 to $74.15^{\circ} \mathrm{C}$ and from 56.45 to $73.91{ }^{\circ} \mathrm{C}$ with different extraction methods and a solution of sodium chloride and sodium bisulfate, using differential scanning calorimetry.

\subsection{Colour evaluation of avocado seed starch}

The lightness $\left(\mathrm{L}^{*}\right)$ was around $73.02 \pm 0.48$, the values of $\left(\mathrm{a}^{\star}\right)$ parameter were $12.47 \pm 0.13$, meanwhile, for the parameter $\left(b^{*}\right)$ it was $31.58 \pm 0.27$. Chroma was $33.96 \pm 0.27$ and Hue was $68.40 \pm 0.07$ indicating a trend towards light yellow (Table 2). According to García-Tejeda et al. (2011) the color parameters of banana starch $\left(\mathrm{L}^{*}\right)$ 81.33, $\left(\mathrm{a}^{*}\right) 4.29$ and $\left(\mathrm{b}^{*}\right) 10.07$ indicated a trend towards light white. Abegunde et al. (2013) reported a brightness for sweet potato starch of $\left(\mathrm{L}^{*}\right) 97.47\left(\mathrm{a}^{*}\right)-1.21$ and $\left(\mathrm{b}^{*}\right) 4.21$ with a trend towards light yellow. The starch obtained in this study was different from sweet potato starch (Ipomoea batatas) and banana starch (Musa paradisiaca) (Table 3).

\subsection{Biofilms production}

Two types of biofilms were produced by the casting method. The characteristics of the film produced without plasticizer were a rigid material with a brittle nature; the glycerol, addition as a plasticizer, allowed obtaining a biofilm with elastic characteristics as shown in Table 4.

\subsection{Elongation evaluation and fracture stress}

The tensile strength for $\mathrm{T} 1$ was $19.37 \pm 5.31 \mathrm{MPa}$ and for $\mathrm{T} 2$ was $10.78 \pm 1.07 \mathrm{MPa}$; while the elongation for T1 was $3.07 \%$ and for T2 was $13.09 \%$ with a significant difference between them $(p<0.001)$. Pardo et al. (2012) reported an elongation percentage of $16.4 \%$ and a tensile strength of $10.1 \mathrm{MPa}$ in arracacha starch film (Arracacia xanthorrhiza Bancroft) with $0.6 \mathrm{~mL}$ glycerol. This result is similar to the obtained in the T2 film $(0.5 \mathrm{~mL}$ glycerol $)$ and demonstrates that the addition of glycerol positively modified the mechanical properties of the biofilm in terms of elongation.

\subsection{Water vapor permeability}

This analysis evaluated the role that water plays in the deteriorating reactions of food. Table 5 shows T2 is more permeable than $\mathrm{T} 1(\mathrm{p}=0.017)$ due to the addition of glycerol. Guadarrama-Lezama et al. (2018) reported that the nopal and glycerol mucilage film presented a permeability of $2.3 \times 10^{-9} \mathrm{~g} /$ day $\mathrm{mPa}$ which is lower than the value reported for $\mathrm{T} 2 \mathrm{in}$ the present study. Sandoval et al. (2018), reported values of $7.2 \times 10^{-4} \mathrm{~g} /$ day $\mathrm{mPa}$ where Hass avocado seed sifted flour was used to prepare a biofilm. This film structure is compact and presented a higher permeability value, while the flour that was not sifted presented a value of $2.09 \times 10^{-3} \mathrm{~g} /$ day $\mathrm{mPa}$, with a decrease in permeability.

\subsection{Biofilms colour}

The luminosity $\left(\mathrm{L}^{*}\right)$ was 84.3 , the value of the parameter $a^{\star}$ was 7.20 and for the parameter $b^{\star}$ it was 18.62 in the biofilm $\mathrm{T} 1$, indicating a trend towards a transparent appearance. For the T2 biofilm, the value of $\mathrm{L}^{\star}$ was 74.73 , $\mathrm{a}^{*}$ was 10.08 and $\mathrm{b}^{*}$ was 31.10 , indicating a trend towards light yellow (Table 4 ). 


\section{Conclusions}

The technique used for the extraction of starch was based on the wet method obtaining a yield of $11.38 \%$, presenting satisfactory results when characterizing it by FT-IR where the main groups present in starch were observed. The biofilms (T2) made with $2 \mathrm{~g}$ of starch; $70 \mathrm{~mL}$ of water and $0.5 \mathrm{~mL}$ of glycerol were the most suitable since those with no glycerol were rigid and brittle. The glycerol addition allowed to obtain a biofilm with flexible characteristics, proven by mechanical tests, elongation, and water vapor permeability. In T2, glycerol decreased the tensile strength and improved the water vapor permeability due to hydrophilic character. The results indicate that it is possible to use Hass avocado seed waste for starch extraction and produce biofilms to give it added value. This biofilm can be used in low moisture food coatings.

\section{References}

Abegunde, O. K., Mu, T. H., Chen, J. W., \& Deng, F. M. (2013). Physicochemical characterization of sweet potato starches popularly used in Chinese starch industry. Food Hydrocolloids, 33(2), 169-177. http://dx.doi.org/10.1016/j.foodhyd.2013.03.005.

Acosta, L. (2011). Películas comestibles nanoestructuradas de almidón de camote (Ipomea batata) (Tesis de maestría). Universidad Veracruzana, Xalapa, Veracruz.

Alvarado, S., Sandoval, G., Palos, I., Tellez, S., Aguirre-Loredo, Y., \& Velázquez, G. (2015). The effect of relative humidity on tensile strength and water vapor permeability in chitosan, fish gelatin and transglutaminase edible films. Food Science and Technology, 35(4), 690-695. http://dx.doi.org/10.1590/1678-457X.6797.

Alves, I. R., Magnani, M., Medeiros, F. S., Sabino, K., de Souza, J., \& Queiroga-Neto, V. (2017). Characterization of the chemical and structural properties of native and acetylated starches from avocado (Persea americana Mill) seeds. International Journal of Food Properties, 20(1), 279-289. http://dx.doi.org/10.1080/10942912.2017.1295259.

American Society for Testing and Materials - ASTM. (2001a). ASTM D882- 00: standard test methods for tensile properties of thin plastic sheeting. Philadelphia: ASTM.

American Society for Testing and Materials - ASTM. (2001b). ASTM E96-00: standard methods of test for water vapor transmission of materials in sheet form. Philadelphia: ASTM.

Chel-Guerrero, L., Barbosa-Martín, E., Martínez-Antonio, A., GonzálezMondragón, E., \& Betancur-Ancona, D. (2016). Some physicochemical and rheological properties of starch isolated from avocado seeds. International Journal of Biological Macromolecules, 86, 302-308. http://dx.doi.org/10.1016/j.ijbiomac.2016.01.052. PMid:26800900.

Chil-Núñez, I., Molina-Bertrán, S., Ortiz-Zamora, L., Dutok, C. M. S., \& Souto, R. N. P. (2019). Estado del Arte de la especie Persea americana Mill (aguacate). Amazonia Investiga, 8(21), 73-86.

Cornelia, M., \& Christianti, A. (2018). Utilization of modified starch from avocado (Persea americana Mill) seed in cream soup production. IOP Conference Series: Earth and Environmental Science, 102(1), 1-7. http://dx.doi.org/10.1088/1755-1315/102/1/012074.

Correa, V., Vallencilla, L. E., Cárdenas, K., \& Guancha, M. (2019). Memorias, V. S. de materiales poliméricos, Biopolímeros. Informador Técnico, 83(2), 120-123. http://dx.doi.org/10.23850/22565035.258.

Domínguez, M. P., Araus, K., Bonert, P., Sánchez, F., San Miguel, G., \& Toledo, M. (2014). The avocado and its waste: an approach of fuel potential/application. Environment, Energy and Climate Change, 2, 199-223. http://dx.doi.org/10.1007/698_2014_291.
García-Tejeda, Y. V., Zamudio-Flores, P. B., Bello-Pérez, L. A., RomeroBastida, C. A., \& Solorza-Feria, J. (2011). Oxidación del almidón nativo de plátano para su uso potencial en la fabricación de materiales de empaque biodegradables: caracterización física, química, térmica y morfológica. Revista Iberoamericana de Polímeros, 12(3), 125-135.

Ginting, M. H. S., Hasibuan, R., Lubis, M., Alanjani, F., Winoto, F. A., \& Siregar, R. C. (2018). Supply of avocado starch (Persea americana Mill) as bioplastic material. IOP Conference Series. Materials Science and Engineering, 309(1), 012098. http://dx.doi.org/10.1088/1757899X/309/1/012098.

Ginting, M. H. S., Tarigan, F. R., \& Singgih, A. M. (2015). Effect of gelatinization temperature and chitosan on mechanical properties of bioplastics from avocado seed starch (Persea americana Mill) with plasticizer glycerol. International Journal of Engineering Science, 4(12), 36-43.

Grace, M. R. (1977). Elaboración de la yuca. Roma: Organización de las Naciones Unidas para la Agricultura y la Alimentación.

Guadarrama-Lezama, A. Y., Castaño, J., Velázquez, G., Carrillo-Navas, H., \& Alvarez-Ramírez, J. (2018). Effect of nopal mucilage addition on physical, barrier and mechanical properties of citric pectin-based films. Journal of Food Science and Technology, 55(9), 3739-3748. http://dx.doi.org/10.1007/s13197-018-3304-x. PMid:30150834.

Hernández, J. E., Medina, O. J., Hernández, A. L., \& Coha, P. M. (2017). Oxidación y caracterización fisicoquímica de almidón de sagú "Marantha Arundinacea" para la elaboración de bioplástico. Revista Fuentes, 15(1), 19-26. http://dx.doi.org/10.18273/revfue.v15n1-2017002.

Lara-Valencia, V. A., Dávila-Soto, H., Moscoso-Sánchez, F. J., Figueroa-Ochoa, E. B., Carvajal-Ramos, F., Fernández-Escamilla, V. V. A., González-Álvarez, A., Soltero-Martínez, J. F. A., MacíasBalleza, E. R., \& Enríquez, S. G. (2018). The use of polysaccharides extracted from seed of Persea americana var. Hass on the synthesis of acrylic hydrogels. Química Nova, 41(2), 140-150. http://dx.doi. org/10.21577/0100-4042.20170156.

Le Corre, D., Bras, J., \& Dufresne, A. (2010). Starch nanoparticles: a review. Biomacromolecules, 11(5), 1139-1153. http://dx.doi. org/10.1021/bm901428y. PMid:20405913.

Lubis, M., Harahap, M. B., Ginting, M. H. S., Sartika, M., \& Azmi, H. (2016). Effect of microcrystalline cellulose (mcc) from sugar palm fibres and glycerol addition on mechanical properties of bioplastic from avocado seed starch (Persea americana Mill). Proceedings of Engineering \& Technology, Computer, Basics \&. Applied Sciences, 331(3), 1-10.

Martínez, O., Lapo Calderón, B., Pérez Rodriguez, J., Zambrano Cabrera, C., \& Maza Valle, F. (2016). Mecanismo de gelatinización del almidón nativo de banano exportable del Ecuador. Revista Colombiana de Quimica, 44(2), 16-21. http://dx.doi.org/10.15446/ rev.colomb.quim.v44n2.55215.

México, Dirección General de Normas. (1978). NMX-F-066-S-1978: determinación de cenizas en alimentos. México. Retrieved from https://www.colpos.mx/bancodenormas/nmexicanas/NMX-F066-S-1978.PDF

México, Dirección General de Normas. (1986). NMX-F-083-1986: alimentos: determinación de humedad en productos alimenticios. México.

Pardo, O. H., Aperador, W., \& Sanabria, W. M. (2012). Efecto de la modificación del almidón de arracacha y la concentración del plastificante sobre las propiedades mecánicas de películas biodegradables. Prospectiva, 10(1), 37-43.

Pérez, J. M. G. (2014). La edad de los polímeros: un mundo de plástico. España: Editorial Universidad de Burgos.

Pérez, S., Ávila, G., \& Coto, O. (2015). El aguacatero (Persea americana Mill). Cultivos Tropicales, 36(2), 111-123. http://dx.doi.org/10.13140/ RG.2.2.19879.55200. 
Rodríguez-Sepúlveda, L. J., \& Orrego-Alzate, C. E. (2016). Aplicaciones de mezclas de biopolímeros y polímeros sintéticos: revisión bibliográfica. Revista Científica, 2(25), 252-264. http://dx.doi.org/10.14483// udistrital.jour.RC.2016.25.a9.

Sandoval, G., Alvarado, S., Velázquez de la Cruz, G., Martínez, M., \& Jiménez, R. (2018). Desarrollo y optimización de una metodología de síntesis de biopelículas de hueso de aguacate Hass. Revista Ciencia Básica, Ingeniería y Tecnología, (38), 47-51.

Servicio de Información Agroalimentaria y Pesquera - SIAP. (2020). Boletín mensual de producción de aguacate. Ciudad de México: SIAP.
Villalobos, M., López, M., Rodríguez, P., \& Prado, M. (2014). Obtención de almidón a partir de los residuos de papa del mercado Abastos. Guanajuato: Universidad Tecnológica del Suroeste de Guanajuato.

Wang, W., Bostic, T. R., \& Gu, L. (2010). Antioxidant capacities, procyanidins and pigments in avocados of different strains and cultivars. Food Chemistry, 122(4), 1193-1198. http://dx.doi. org/10.1016/j.foodchem.2010.03.114.

Yadav, A., Mangaraj, S., Singh, R., Kumar, N., \& Arora, S. (2018). Biopolymers as packaging material in the food and allied industries. International Journal of Chemical Studies, 6(2), 2411-2418. 